2012

Statins in Unconventional Secretion of

Insulin-Degrading Enzyme and

Degradation of the Amyloid- Peptide

Glebov, Konstantin

http://hdl.handle.net/10026.1/13248

$10.1159 / 000332595$

Neurodegenerative Diseases

S. Karger AG

All content in PEARL is protected by copyright law. Author manuscripts are made available in accordance with publisher policies. Please cite only the published version using the details provided on the item record or document. In the absence of an open licence (e.g. Creative Commons), permissions for further reuse of content should be sought from the publisher or author. 


\title{
Statins in Unconventional Secretion of Insulin-Degrading Enzyme and Degradation of the Amyloid- $\beta$ Peptide
}

\author{
Konstantin Glebov Jochen Walter \\ Department of Neurology, University of Bonn, Bonn, Germany
}

\section{Key Words}

Alzheimer's disease $\cdot$ Metalloproteinase $\cdot$ Unconventional secretion $\cdot$ Insulin-degrading enzyme $\cdot$ SlyX motif $\cdot$ Statins

\begin{abstract}
Population-based studies demonstrated that statins might decrease the risk of developing Alzheimer's disease (AD). Statins inhibit the 3-hydroxy-3-methyl-glutaryl-coenzymeA reductase and thereby de novo synthesis of cholesterol. Cell culture and animal studies indicated that cholesterol affects the proteolytic processing of the amyloid precursor protein and the generation of amyloid- $\beta(A \beta)$. Recently, we have demonstrated that statins can also stimulate the degradation of $A \beta$. The statin-induced clearance of $A \beta$ could be attributed to increased release of the insulin-degrading enzyme (IDE) via an exosome-related unconventional secretory pathway. Interestingly, this statin-induced secretion of exosome-associated IDE was independent of cellular cholesterol concentrations, but rather caused by impairment of isoprenoid biosynthesis and protein prenylation. We further identified a new hexapeptide sequence in the C-terminal region of IDE, named the SlyX motif that is critically involved in IDE secretion. Taken these findings together, the increased clearance of $A \beta$ by stimulated secretion of IDE might contribute to the protective effects of statins against AD.

Copyright $\odot 2011$ S. Karger AG, Basel
\end{abstract}

\section{KARGER}

Fax +4161306 1234

E-Mail karger@karger.ch

www.karger.com
C 2011 S. Karger AG, Basel

$1660-2854 / 12 / 0104-0309 \$ 38.00 / 0$

Accessible online at:

www.karger.com/ndd

\section{Statins and Alzheimer's Disease}

Epidemiological studies indicate that statins exert a beneficial effect against the development of Alzheimer's disease (AD) [1-3]. While the underlying mechanisms are unclear, cellular and animal studies showed that changes in membrane cholesterol affect the proteolytic generation of amyloid- $\beta$ (A $\beta)$ from the amyloid precursor protein. $A \beta$ is a major component of extracellular plaques in $\mathrm{AD}$ patients and exerts neurotoxicity [4-6]. Most studies indicate that lowering cholesterol levels decreases the secretion of $A \beta$. However, moderate reduction of cholesterol could also promote the generation of $A \beta$ in neuronal cells [7]. The cholesterol-dependent generation of $A \beta$ could involve changes in the distribution of certain secretases and the amyloid precursor protein (APP) in distinct subcellular compartments and membrane microdomains/lipid rafts [7-10].

Statins inhibit 3-hydroxy-3-methyl-glutaryl-coenzyme-A reductase (HMGCR), a rate-controlling enzyme in the mevalonate pathway that not only produces cholesterol, but also isoprenoids [11]. Statins affect various (patho)physiological processes, like atherosclerosis, vascular inflammation, platelet activation, blood coagulation, and smooth muscle cell proliferation $[12,13]$. However, the relative contribution of cholesterol and isoprenoid metabolism to these effects is largely unknown. 


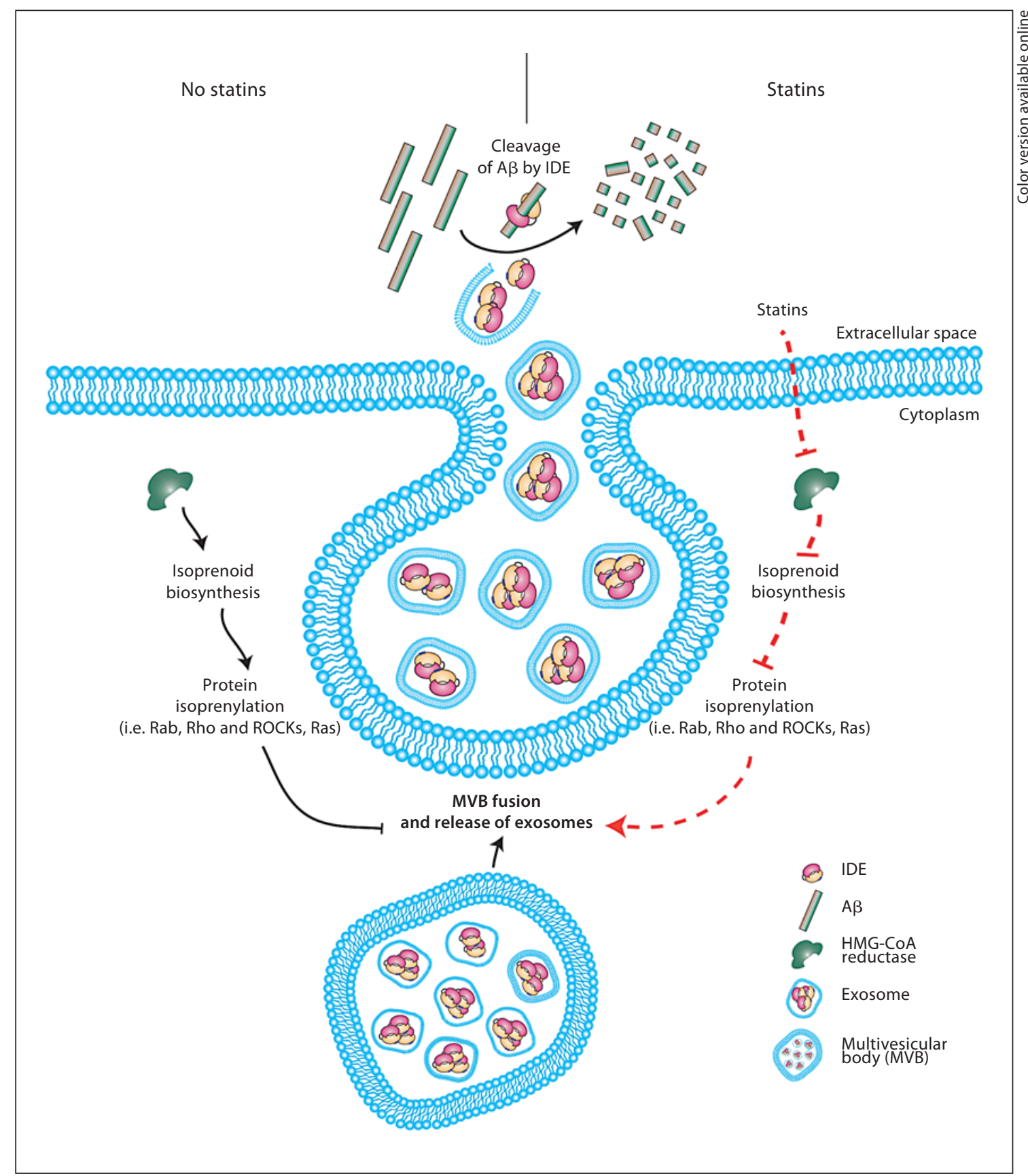

Fig. 1. Suggested mechanism of statin-stimulated $A \beta$ degradation by release of exosome-associated IDE. Exosomes correspond to intraluminal vesicles of endosomal multivesicular bodies released upon fusion with the plasma membrane. Isoprenoids are synthesized in the mevalonate pathway. HMGCR is the rate-controlling enzyme in the biosynthesis of both cholesterol and isoprenoids, thereby regulating the isoprenylation of different proteins like
Ras, Rab, Rho and ROCKs. Statins inhibit HMGCR, and thus also decrease protein prenylation. The decrease in protein prenylation stimulates the fusion of multivesicular bodies and release of exosomes containing IDE. IDE might be released upon breakage of exosomes allowing the degradation of extracellular $\mathrm{A} \beta$ (see text for details). MVBs = Multivesicular bodies. 


\section{Unconventional Release of Insulin-Degrading Enzyme Involves Exosomes}

Recently, we demonstrated that statins induce the release of the insulin-degrading enzyme (IDE) in association with exosomes from microglia cells and thereby promote the clearance of extracellular A $\beta$ [14] (fig. 1). IDE is a $\mathrm{Zn}^{2+}$ metalloproteinase and degrades insulin, but also a number of additional peptides, including $A \beta$.

While mainly localized in the cy tosol, IDE can also be released from cells and found in extracellular fluids and conditioned media of cultured cells [15-17]. It lacks a classical signal sequence that targets it to the conventional secretory pathway. By utilizing bioinformatical and biochemical approaches, we have recently identified a novel motif within the inactive protease domain III of IDE, which we called the SlyX motif [18]. This hexapeptide motif ('EKPPHY') shares 100\% homology with an amino acid sequence in the $\mathrm{C}$ terminus of the bacterial SlyX protein. Its deletion significantly reduces the secretion of IDE from cultured cells. In turn, fusion of the SlyX motif to GFP, which was expressed in the cytosol, improved its secretion into the medium. Notably, the SlyX motif is also found in other proteins, like heparan sulfate proteoglycans or phospholipid scramblase 1 that undergo unconventional secretion pathways.

The unconventional secretion of proteins could be mediated via exosomes, small 40- to 100 -nm cup-shaped vesicles found in extracellular fluids like blood, urine, and cerebrospinal fluid $[19,20]$. Exosomes may modulate several biological processes, including inflammation, cell differentiation and proliferation [20-22]. Cell biological studies indicate that exosomes originate from intralumi- nal vesicles of multivesicular bodies upon fusion with the cellular plasma membrane [20]. They are enriched in cholesterol, sphingolipids and ceramide, which are also present in lipid rafts and further contain certain proteins like Rab GTPases, flotillin, integrins and tetraspanins [20]. However, little is known about the molecular machinery involved in the regulation of exosome secretion. Only recently has it been shown that some Rab proteins, like Rab35, are involved in exosome release [23]. In addition, other prenylated proteins involved in vesicular trafficking, like Ras, Rho and ROCK proteins, might also contribute to this pathway. Interestingly our data indicate that the statin-induced secretion of exosomes and the clearance of $A \beta$ are due to the inhibition of protein prenylation [14]. Since Rab proteins are regulated by isoprenylation [24], it will be interesting to analyze whether statins affect the isoprenylation of certain Rab or other proteins, that are involved in unconventional secretion.

\section{Conclusions}

The recent identification of an amino acid-based signal in IDE and its unconventional secretion via exosomes helped to understand the mechanisms underlying the extracellular occurrence of this enzyme. As statins strongly stimulate exosome release, the beneficial effects of these drugs against $\mathrm{AD}$ pathogenesis could involve stimulation of extracellular $A \beta$ degradation. It will now be interesting to further characterize the identified pathway as well as to specifically stimulate secretion of endogenous IDE in therapeutic and/or preventive strategies against $\mathrm{AD}$.

\section{References}

- 1 Jick H, Zornberg GL, Jick SS, Seshadri S, Drachman DA: Statins and the risk of dementia. Lancet 2000;356:1627-1631.

-2 Haag MD, Hofman A, Koudstaal PJ, Stricker $\mathrm{BH}$, Breteler MM: Statins are associated with a reduced risk of Alzheimer disease regardless of lipophilicity. The Rotterdam Study. J Neurol Neurosurg Psychiatry 2009;80:1317.

-3 Wolozin B, Kellman W, Ruosseau P, Celesia GG, Siegel G: Decreased prevalence of Alzheimer disease associated with 3-hydroxy-3-methyglutaryl coenzyme A reductase inhibitors. Arch Neurol 2000;57:14391443.
4 Hartmann T: Cholesterol, A beta and Alzheimer's disease. Trends Neurosci 2001; 24:S45-S48.

5 Glenner GG, Wong CW: Alzheimer's disease: initial report of the purification and characterization of a novel cerebrovascular amyloid protein. Biochem Biophys Res Commun 1984;120:885-890.

6 Liao L, Cheng D, Wang J, Duong DM, Losik TG, Gearing M, Rees HD, Lah JJ, Levey AI, Peng J: Proteomic characterization of postmortem amyloid plaques isolated by laser capture microdissection. J Biol Chem 2004; 279:37061-37068.
7 Abad-Rodriguez J, Ledesma MD, Craessaerts K, et al: Neuronal membrane cholesterol loss enhances amyloid peptide generation. J Cell Biol 2004;167:953-960.

8 Cheng H, Vetrivel KS, Gong P, Meckler X, Parent A, Thinakaran G: Mechanisms of disease: new therapeutic strategies for Alzheimer's disease - Targeting APP processing in lipid rafts. Nat Clin Pract Neurol 2007;3: 374-382.

9 Ehehalt R, Keller P, Haass C, Thiele C, Simons K: Amyloidogenic processing of the Alzheimer beta-amyloid precursor protein depends on lipid rafts. J Cell Biol 2003;160: 113-123. 
10 Kojro E, Gimpl G, Lammich S, Marz W, Fahrenholz F: Low cholesterol stimulates the nonamyloidogenic pathway by its effect on the alpha-secretase ADAM 10. Proc Natl Acad Sci USA 2001;98:5815-5820.

11 Longenberger J, Shah ZA: Simvastatin and other HMG-CoA reductase inhibitors on brain cholesterol levels in Alzheimer's disease. Curr Alzheimer Res 2011; 8:434-442.

12 Miida T, Hirayama S, Nakamura Y: Cholesterol-independent effects of statins and new therapeutic targets: ischemic stroke and dementia. J Atheroscler Thromb 2004;11:253264.

13 Takemoto M, Liao JK: Pleiotropic effects of 3-hydroxy-3-methylglutaryl coenzyme a reductase inhibitors. Arterioscler Thromb Vasc Biol 2001;21:1712-1719.

14 Tamboli IY, Barth E, Christian L, et al: Statins promote the degradation of extracellular amyloid- $\beta$ peptide by microglia via stimulation of exosome-associated IDE secretion. J Biol Chem 2010; 285:37405-37414.
15 Bulloj A, Leal MC, Xu H, Castano EM, Morelli L: Insulin-degrading enzyme sorting in exosomes: a secretory pathway for a key brain amyloid-beta degrading protease. J Alzheimers Dis 2010;19:79-95.

16 Qiu WQ, Walsh DM, Ye Z, Vekrellis K, Zhang J, Podlisny MB, Rosner MR, Safavi A, Hersh LB, Selkoe DJ: Insulin-degrading enzyme regulates extracellular levels of amyloid beta-protein by degradation. J Biol Chem 1998;273:32730-32738.

17 Zhao J, Li L, Leissring MA: Insulin-degrading enzyme is exported via an unconventional protein secretion pathway. Mol Neurodegener 2009;4:4.

18 Glebov K, Schutze S, Walter J: Functional relevance of a novel SlyX motif in non-conventional secretion of insulin-degrading enzyme. J Biol Chem 2011;286:22711-22715.

19 Keller S, Ridinger J, Rupp AK, Janssen JW, Altevogt P: Body fluid derived exosomes as a novel template for clinical diagnostics. J Transl Med 2011;9:86.
0 Simons M, Raposo G: Exosomes - Vesicular carriers for intercellular communication. Curr Opin Cell Biol 2009;21:575-581.

21 Admyre C, Telemo E, Almqvist N, et al: Exosomes - Nanovesicles with possible roles in allergic inflammation. Allergy 2008; 63: 404-408.

22 Taverna S, Flugy A, Saieva L, et al: Role of exosomes released by chronic myelogenous leukemia cells in angiogenesis. Int J Cancer 2011, DOI: 10.1002/IJC.26217.

23 Hsu C, Morohashi Y, Yoshimura S, et al: Regulation of exosome secretion by Rab35 and its GTPase-activating proteins TBC1D10AC. J Cell Biol 2010;189:223-232.

24 Leung KF, Baron R, Seabra MC: Thematic review series: lipid posttranslational modifications. Geranylgeranylation of Rab GTPases. J Lipid Res 2006;47:467-475. 